УДК: 35.001 .73

DOI: https://doi.org/10.32689/2618-0065-2020-2(4)-228-238

Лях Юлія Іванівна, асистент кафедри Менеджменту і публічного адміністрування, Харківський національний університет міського господарства імені О. М. Бекетова, 61002, Україна, м. Харків, вул. Маршала Бажанова, 17 тел.: (057) 707-31-09, e-mail: kharkov.yuliya@gmail.com, https://orcid.org/0000-0002-0477-1772.

\title{
ЗАРУБІЖНИЙ ДОСВІД МОДЕРНІЗАЦІЇ ПУБЛІЧНОГО УПРАВЛІННЯ ТА ПЕРСПЕКТИВИ ЙОГО ЗАСТОСУВАННЯ В УКРАЇ̈I
}

Анотація. Важливість і необхідність грунтовного дослідження обраної теми полягає в тому, що демократизація суспільної життєдіяльності українського суспільства та розвиток сучасної системи державного управління вимагають модернізації публічного управління, виявлення нових принципів, цінностей, ефективних механізмів управління. Перед органами публічної влади стоїть завдання 3 впровадження в систему публічного управління ефективних форм управління, що здатні забезпечити можливість кожного громадянина реалізовувати та задовольняти власні потреби та інтереси. Від здатності та можливостей органів публічної влади вирішувати проблеми громадян залежить ефективність системи публічного управління. Забезпечення комунікаційних взаємовідносин між суб'єктами й об'єктами публічного управління, вільний доступ громадян до інформації на всіх етапах прийняття рішень обумовлює необхідність модернізації сучасної системи публічного управління, 3 метою підвищення іiі ефективності, результативності та поліпшення якості надання послуг населенню. Реалізація цього процесу вбачається в забезпеченні громадського контролю, електронного врядування, в можливості прийняття безпосередньої участі інститутів громадянського суспільства в роботі експертних, громадських рад, у консультативнодорадчих органах задля вираження та захисту прав i свобод громадян. Обгрунтуванню перелічених заходів передують наукові дослідження щодо модернізації публічного управління в розвинених країнах світу і практики реалізації принципів публічного управління.

Доведено, що основними тенденціями модернізації публічного управління в зарубіжних країнах $є$ : використання передових інформаційнокомунікаційних технологій у сфері публічного управління; підвищення контролю за діяльністю органів державної влади; вдосконалення механізму «єдиного вікна»; підвищення рівня якості надання державних і 
адміністративних послуг; розвиток системи громадського контролю за витрачанням бюджетних коштів; налагодження зворотного зв’язку в сфері публічного управління, децентралізація влади як інструмент демократизації публічного управління.

Досліджено можливості використання передового прогресивного зарубіжного досвіду в практиці модернізації публічного управління в Україні, запропоновано шляхи вирішення існуючих проблем з урахуванням досвіду країн Свропи та США.

Ключові слова: публічне управління, модернізація, права людини, демократизація

Liakh Yuliia Ivanivna, Assistant of the Department of Management and Public Administration, O. M. Beketov National University of Urban Economy in Kharkiv, 17, Marshal Bazhanov Street, Kharkiv, 61002, Ukraine, tel.: (057) 707-3109, e-mail: kharkov.yuliya@gmail.com, https://orcid.org. 0000-0002-0477-1772.

\section{FOREIGN EXPERIENCE OF MODERNIZATION OF PUBLIC ADMINISTRATION AND PROSPECTS OF ITS APPLICATION IN UKRAINE}

Abstract. The importance and necessity of the extensive research of the chosen theme is that the democratization of the social activity of Ukrainian society and the development of a modern system of public administration require the modernization of public administration, the identification of new principles, values and effective governance mechanisms. The public authorities are faced with the task of introducing into the public administration system effective forms of management, capable of ensuring the possibility of each citizen to realize and satisfy his own needs and interests. The capabilities and opportunities of public authorities to deal with citizens' problems depend on the effectiveness of the public administration system. Ensuring communication relationship between subjects and objects of public management, free access of citizens to information at all stages of decision-making causes need of modernization of a current system of public management, for the purpose of increase in its efficiency, effectiveness and improvement of quality of provision of services to the population. The implementation of this process is considered in the provision of public control, electronic governance, the possibility of taking direct participation of civil society institutions in the work of expert and public councils, in consultative and advisory bodies for the expression and protection of the rights and freedoms of citizens. The justification of these events is preceded by scientific research on modernization of public administration in developed countries of the world and practice of implementation of principles of public management. 
The use of advanced information and communication technologies in the field of public administration; increased control over the activities of state authorities; improvement of the single-window system; improving the quality of public and administrative services; development of a system of public control over budgetary expenditures; obtaining feedback in the field of public administration, decentralization of power as a tool for democratization of public administration are proved to be the main trends of modernization of public administration in foreign countries.

The possibilities of using advanced progressive foreign experience in the practice of modernization of public administration in Ukraine have been studied, ways of solving existing problems taking into account the experience of the countries of Europe and the USA have been proposed.

Keywords: public administration, modernization, human rights, democratization.

Постановка проблеми. Науковці та державні діячі значну увагу надають проблемам модернізації публічного управління. Це обумовлено соціальними трансформаціями, що відбуваються в Україні. Досі існують протиріччя в розвитку публічного управління: забюрократизованість системи, низька ефективність, нерозвиненість демократичних процедур управління тощо. Тому, актуальним є ознайомлення зі світовою управлінською думкою та історичними передумовами щодо модернізації системи публічного управління, визначення ефективних принципів публічного управління та впровадження зарубіжного досвіду в розумному його поєднанні 3 вітчизняними напрацюваннями та традиціями. Принципи зарубіжного демократичного врядування необхідно впроваджувати поступово, щоб не спричинити негативних наслідків, змінюючи вітчизняну державно-управлінську діяльність, ментальність задля успішного розвитку та входження до європейського і світового співтовариства.

Аналіз останніх досліджень і публікацій. Дослідженню процесів модернізації публічного управління присвячено достатньо багато робіт як українських, так і зарубіжних науковців. Незначна кількість наукових публікацій, що дозволяють вивчити й осмислити європейський досвід проведення модернізації публічного управління були перекладеними 3 іноземних джерел. Серед українських дослідників, що проводили відповідні дослідження є В. Бакуменко, М. Лахижа, В. Авер'янов, О. Оболенський, Л. Шереметьєв, В. Солових, Х. Хачатурян, А. Варягіна, І. Белей, В. Князев, О. Руденко, В. Луговий та ін. Значна увага в наукових працях цих дослідників надається питанням щодо проблем побудови ефективної системи публічного управління. На цій основі сформульовані основні напрями модернізації публічного управління в Україні. Разом із тим, незважаючи на досить грунтовний і масштабний розгляд проблем модернізації системи публічного 
управління в контексті розвитку взаємодії інститутів громадянського суспільства та правової держави, існує потреба комплексного дослідження тенденцій щодо форм і методів взаємодії.

Метою статті $\epsilon$ дослідження тенденцій модернізації публічного управління в провідних країнах світу, визначення передумов, критерій модернізації публічного управління, виокремлення найбільш сприятливих для України шляхів модернізації, грунтуючись на досвіді країн Свропи та США.

Виклад основного матеріалу. В силу низки історичних, соціальноекономічних, політичних чинників, прогресивні країни світу досить швидко відреагували на виклики глобалізації в усіх сферах життєдіяльності людини. Пройшовши достатньо довгий шлях у розвитку взаємовідносин між суб’ єктами і об’єктами публічного управління, провідні країни світу на сьогодні мають напрацьований позитивний досвід побудови комунікативної парадигми, який може бути корисним для України в умовах трансформаційних змін у публічному управлінні. Характерною рисою модернізації публічного управління в зарубіжних країнах $\epsilon$ те, що вони грунтуються на засадах демократичного врядування з орієнтацією на людину-громадянина.

Для України модернізація публічного управління полягає в запровадженні інституційних принципів демократичного управління, що здатно забезпечити вимоги сьогодення, досягнення максимальних результатів урядування, гарантування відповідальності органів державної влади перед громадськістю. Відповідні інститути мають потенційну можливість враховувати думку громадськості при прийнятті управлінського рішення. Зважаючи на це, модернізація публічного управління України може перейняти досвід становлення публічного управління в успішних країнах Європи та США.

Таким чином, модернізація публічного управління, потребує демократизації взаємовідносин між суб’єктами і об’єктами управління, впровадження демократичних механізмів організації діяльності органів державної влади, оскільки «без використання в діяльності органів державної влади демократичних форм і технологій ведення управлінських дій неможливо досягнути її належної раціональності та ефективності» [1].

Донедавна в більшості країн світу була ієрархічна (вертикальна) побудова державної влади, в якій дії громадськості були обмежені бюрократичними правилами, мало місце підпорядкування нижчого управлінського рівня вищому. Поступово, впровадження принципів демократичного врядування забезпечили правом різні соціальні групи можливістю висловлювати власні думки та бути почутими, а влада, в свою чергу, заохочувала налагодження зворотних зв’язків 3 громадськістю та змінювала систему адміністрування в бік максимальної публічності. Це призвело до зростання довіри до органів влади, адже «зв’язки зі суспільством - це, перш за все, налагодження взаєморозуміння та довіри, а корні цього явища 
сягають далеко в історію» [2, с. 50]. В даному контексті, під «зв'язками 3 громадськістю» мається на увазі процес становлення довіри до влади шляхом своєчасного, повного та достовірного інформування суспільства про свою діяльність, налагодження комунікаційних зв'язків, знаходженню консенсусу у вирішенні питань публічної політики. Зв'язки з громадськістю обумовлюють, перш за все, налагодження каналів комунікацій, котрі доносять повідомлення до цільової аудиторії - громадськості, та забезпечують 3 нею зворотний зв'язок, що $є$ значним чинником демократизації системи публічного управління. Дослідники зазначають, що «на практиці, одна з вимог демократії включає в себе двосторонній процес спілкування між суб'єктами та об'єктами управління, що передбачають відносини між ними, засновані на довірі» [33, с. 11]. Американці були одними з перших, хто звернувся до проблеми соціальної місії та соціальної відповідальності. Відображенням цього стала модель Дж. Грюнига [4]. Ї̈ї концепція демонструє зв'язок влади 3 громадськістю, який еволюціонує від односторонньої комунікації до двосторонньої. Даний процес характеризується різноманітними методами впливу на суспільну свідомість від маніпуляцій та пропаганди до формування спільної думки на паритетних i рівноправних принципах, що передбачає консенсус, правдиве інформування та співпрацю суб'єктів і об'єктів публічного управління.

В 1969 році Ш. Арнштейн [55] запропонувала теорію формування публічного управління через модель громадської участі під назвою «Сходи участі громадян» (табл.1), в якій визначила динаміку становлення публічної влади.

Таблиця 1

Сходи участі громадян у публічному управлінні (за Ш. Арнштейн) [55]

\begin{tabular}{|l|c|}
\hline Громадський контроль & \\
\hline Делегування повноважень & \\
\hline Партнерство & \\
\hline & \\
\hline Заспокоєння & Символічні заходи \\
\hline Консультування & \\
\hline Інформування & \\
\hline Психотерапія & Відсутність участі \\
\hline Маніпулювання & \\
\hline
\end{tabular}

На перших сходах участь громадян майже не враховується, натомість, на останніх сходах демонструється переважна участь громадян в управлінні. Тобто, чим вище на сходах, тим більше можливостей у громадян щодо впливу на прийняття владних рішень. Дві нижні сходинки - маніпуляції та психотерапії - не сприяють участі громадян в управлінні, тому їх слід уникати. Наступні три - інформування, консультації та примирення - дозволяють 
громадянам мати голос і бути почутими, але їх погляди не можуть бути належним чином розглянуті можновладцями. Останні три сходинки партнерство, делегована влада та громадський контроль - сприяють реальному впливу громадян на реалізацію узгодженого 3 ними рішення влади. Тим самим, зарубіжна практика демократичного врядування демонструє, що рівень і якість управлінських рішень органів влади, їх здатність своєчасно адаптуватися до змін у суспільному середовищі, багато в чому залежить від дієвості громадського контролю. Вчасне корегування управлінських рішень сприяє економії всіх ресурсів (фінансових, матеріальних, людських, часових тощо), тому формування системи громадського контролю над інститутами публічної влади являється першочерговим завданням при модернізації політичної системи багатьох країн.

Застосування концепції участі громадян набула широкого розповсюдження в США, Великобританії, Канаді, Німеччині, Польщі, Данії та інших провідних країнах світу. Світова практика вдосконалення публічного управління зорієнтована, перш за все, на покращення та забезпечення високого та гідного рівня життєдіяльності населення. У визначенні рівня життя застосовують кількісні та якісні показники. До кількісних відносять рівень обсягу доходів і споживання конкретних товарів і послуг, а якісні - визначають добробут населення. Високий рівень якості життя населення є провідним критерієм високорозвиненої держави. Індикаторів рівня життя на сьогодні існує велика кількість і кожна окрема країна видозмінює їх під свій устрій.

Розвинена й ефективна форма громадської участі проявляється на рівні відкритого партнерства влади з громадянами, дієвого представництва інтересів громадян в органах влади, в продуктивному громадському контролі за владою. Тобто, сфера публічного управління децентралізується та перерозподіляється між суб’єктами й об’єктами публічного управління. Суб’єкти публічного управління діляться прерогативами розробки та прийняття рішень, а значить, $\mathrm{i}$ своєю відповідальністю.

Різні країни світу використовують багатоманітні підходи в модернізації публічного управління. Так, у 1980 - 1990-х рр. США були сформульовані пропозиції щодо побудови системи державного управління на засадах ринкових інститутів з орієнтацією на надання послуг громадянам- «клієнтам» і переходу до «нового публічного менеджменту». В результаті була розроблена та реалізована модель «націленого на результат» державного сектору, в якій результатом визнавалися якісні послуги, задоволеність громадян функціонуванням державного апарату. Основною ціллю уряду стало поліпшення своєї роботи при істотній економії витрат на адміністрування. Також американське врядування здебільш грунтується на фактичному дотриманні прав і свобод громадян, їх права голосу, свободи інформації, народовладдя, що унеможливлює зловживання владою. В США довіра та взаєморозуміння між владою та суспільством було започатковано в сфері 
публічного управління на етапах його формування, а саме, 3 моменту прийняття «Декларації незалежності США» (1776 р.). Цей документ спирався на ідеї, доволі революційні в ті часи, що «всі люди створені рівними, та всі обдаровані своїм творцем природженими та невід'ємними правами, до числа яких належать життя, воля та прагнення до щастя; для забезпечення цих прав серед людей засновані уряди, які запозичують свою справедливу владу в громадськості» [8]. Визначально, що принципи американської декларації незалежності не втратили своєї актуальності й у наш час. Конституція США $є$ найстарішою в світі, вона майже не змінювалася, хоча «американська демократія постійно перебуває в стані еволюційного розвитку» [99].

Корисним для України також може бути британський досвід публічного управління. У Великобританії застосовуються методи взаємодії органів влади та громадянського суспільства з використанням ідей програм «Active Citizens» i «Citizens' Jury». Характерним $\epsilon$ те, що ці програми спрямовані на налагодження ефективних взаємовідносин влади 3 організаціями громадянського суспільства шляхом його залучення до розробки та прийняття соціально-політичних рішень на засадах політичного діалогу з представниками інтересів громадян. Концепція цих програм зобов'язує пересічного громадянина залучатися до прийняття та виконання владних рішень.

У Німеччині модернізація державного управління по відношенню до політичного режиму почалася в XVIII ст. Характерними рисами цього процесу був пошук компромісу між громадськістю та вимогами управління, пошук відповідного механізму модернізації в контексті наявності відповідного законодавства. Для німців надання переваг законам - $є$ ключовим механізмом реалізації волевиявлення конституційно-організованого суспільства. Організаційні й адміністративні принципи державного управління Німеччини базуються на суворому додержанні встановлених законів, «визначальними витоками німецької системи державного управління $\epsilon$ гіпертрофований раціоналізм, висока формалізація всіх процедур» [1010].

У $80-\mathrm{x}$ роках XX ст. у Німеччині та низки західних країн (Великобританія, Нова Зеландія, Австралія, США тощо) модернізація публічного управління носило послідовний i погоджувальний характер. Процес модернізації включав децентралізацію влади, забезпечення ефективності місцевого самоврядування, вдосконалення діяльності управлінських структур усіх рівнів за широкого залучення громадян до процесів прийняття рішень. Реформування передбачало наступні кроки: дебюрократизацію, дерегуляцію, децентралізацію, реформування бюджетного процесу, поліпшення якості надання послуг і задоволення інтересів громадськості, демократизація державного сектору та посилення публічності та відкритості. Аналіз зарубіжного досвіду модернізації публічного управління в країнах США, Великобританії, Німеччини дозволяє узагальнити найбільш 
розповсюджені заходи щодо забезпечення належного рівня публічного управління в умовах його демократизації:

- широке застосування передових інформаційно-комунікаційних технологій у сфері державного управління (функціонування порталів публічного обговорення законопроектів);

- затвердження адміністративних регламентів (стандартів) на надання державних та регіональних послуг у електронному форматі (надання електронних послуг);

- підвищення контролю за діяльністю органів державної влади й органів місцевого самоврядування;

- вдосконалення механізму «єдиного вікна» в роботі органів виконавчої влади;

- підвищення рівня якості наданих державних і адміністративних послуг, а також задоволеність громадськості результатами діяльності органів державної влади і місцевого самоврядування, завдяки отриманню консенсусу у вирішенні владних питань;

- впровадження системи громадського контролю за витрачанням бюджетних коштів;

- вдосконалення державної управлінської політики на засадах зворотного зв'язку.

Наразі в Україні спостерігається невідповідність можливостей прийняття участі громадян у політико-владних відносинах задекларованих у Конституції України та відповідних законах прав і свобод. Це $\epsilon$ наслідком досвіду тоталітарного режиму, який був закладений в 30-х роках XX ст. У Радянській Росії та переходу від авторитарної командно-адміністративної системи до демократичної, плюралістичної. Політичні процеси, що діяли в пострадянські часи, мали суперечності. Поширення політико-організаційних заходів з розвитку демократії, по суті, не відповідали авторитарнопатріархальній політичній культурі, яка панувала в той час у суспільстві. Не відбувалося принципових змін у виборчій системі; не здійснювалось надання більшого спектру повноважень вищим і місцевим органам державної влади тощо. Ці чинники вплинули на досить низькі темпи розвитку демократичних форм управління в Україні. В зв'язку 3 цим в умовах сьогодення спостерігається розрив між прийняттям достатньо обгрунтованого політичного правового рішення за участю громадян та подальшим його виконанням. Також, можна спостерігати, що невиконання або безвідповідальне виконання прийнятих рішень відбувається внаслідок низької політико-правової культури чиновників, якій притаманний правовий нігілізм і відсутність правових механізмів.

Отже, в сфері публічного управління в Україні недостатньо розвинений механізм зворотного зв'язку з громадянами, що не сприяє більш чіткому формуванню рішень суспільно-значущих проблем у соціальній сфері. В 
великій мірі це пов’язано з закритістю та неефективною діяльністю владних структур, у результаті якої громадськість не отримує своєчасного захисту своїх прав і інтересів, і не має достатньої можливості впливати на формування соціальної політики держави.

Натомість, досвід розвинених країн світу доводить, що комунікації між суб’єктами й об’єктами публічного управління $\epsilon$ ефективними та результативними в разі розвиненості демократичних відносин, відкритості та прозорої діяльності публічно-владної системи. На активізацію участі громадськості в політиці європейських держав впливають наступні політикоправові чинники: демократичний правовий режим; правова забезпеченість демократичних процедур формування всіх структур влади; прийняття та реалізація політико-правових рішень на належному рівні; участь громадськості на всіх етапах проведення політичного процесу.

Висновки. У процесі аналізу зарубіжного досвіду встановлено, що значна кількість країн здійснюють масштабні модернізаційні зміни 3 метою адаптації системи публічного управління до реалій глобалізації. Форми, масштаби та темпи перетворень у цих країнах відрізняються. Спільними напрямами модернізації публічного управління в країнах Європи та США встановлено: посилення відкритості органів державної влади, задоволення потреб і інтересів громадян, покращення комунікаційних взаємовідносин між суб’єктами та об’єктами публічного управління. Виявлено, що модернізація публічного управління передбачає трансформацію філософії та культури чиновників публічного управління, методологічним інструментом модернізації виступає концепція держави, орієнтованої на громадянина. Тому підвищення ефективності публічного управління вбачається в розвитку системи, зорієнтованої на взаємодію 3 громадськістю, налагодження комунікаційних відносин, знаходження спільного консенсусу та зміну ментальності громадян.

Для відтворення зарубіжного досвіду модернізації публічного управління в Україні, необхідно врахувати національні традиції, ціннісні настанови, менталітет. Зважаючи на зазначене, сталий рівень життя населення України в умовах демократизації передбачає модернізацію системи публічного управління на засадах прав людини, правозахисних підходах у контексті парадигми комунікаційних відносин між суб'єктами й об'єктами публічного управління; створення прозорих і відповідальних органів державної влади та місцевого самоврядування; висвітлення на офіційних сайтах показників діяльності уряду та забезпечення доступу до цих інтерфейсів усіх громадян; формування партнерських взаємовідносин влади 3 суспільством. Зазначена модернізація системи публічного управління потребує дотримання визначених концептуальних і стратегічних засад модернізації; законодавчого закріплення та забезпечення механізму реалізації основних принципів; моніторингу нормативно-правових актів 3 можливістю усунення 
виявлених недоліків; створення діючих, а не декларативних механізмів відкритості та прозорості державної служби.

\section{Jimepamypa:}

1. Власенко С. Г. Оптимізаційні напрямки демократизації державного управління України / С. Г. Власенко // Ефективність державного управління. - 2016. - Вип. 3. - С. 290296.

2. Харрисон Ш. Связи с общественностью: Вводный курс / Пер. с англ. под ред. Г. Е. Алпатова. - СПб.: Издательский Дом "Нева". - 2003. - 368 с.

3. Richard Chapman, Michael Hunt Open Government : A Study Of The Prospects Of Open Government Within The Limitations Of The British Political System. - Londres: Routledge. 1987.

4. Grunig J.E., Grunig L. Models of PR and communication // Excellence in Public Relations and Communication Management / Ed. by J. Grunig. Hillsdale. - NJ: Lawrence Erlbaum Associates, 1992. - P. 285-326.

5. Варягіна А. А. Критерії оцінки та показники ефективності процесу громадської участі // Теоретичні і прикладні проблеми психології. - 2014. - № 3 (35). - С. 99-108.

6. Wilcox D. The Guide to Effective Participation. - Brighton, UK: Partnership Books. 2001.

7. Солових В. П. Концепція "соціальної держави" та її вплив на державне управління / В. П. Солових // Актуальні проблеми державного управління. - 2009. - № 2. - С. 71-80. Режим доступу: http://nbuv.gov.ua/UJRN/apdy_2009_2_10

8. Чанинг Э. История Соединенных Штатов Северной Америки (1765 -1865 г.г.) / пер. с англ. А. Каменский. - СПб.: Типография контрагентства ж.д. - 1897 г. - 382 с. - Режим доступа https://ushistory.ru/images/files/channing_US_H.pdf

9. Белей Ірина. Зарубіжній досвід демократичного врядування та можливості його застосування в українській практиці / I. Белей // Державне управління та місцеве самоврядування. - Дніпро: ДРІДУ. - №2 (5). - 2010. - Режим доступу http://www.dridu.dp.ua/vidavnictvo/2010/2010_02(5)/10bimzup.pdf

10. Терещенко Д. А. Прийняття управлінських рішень у діяльності органів державної влади: аналіз світового досвіду / Д. А. Терещенко // Актуальні проблеми державного управління: зб. наук. пр. / редкол. : Л. О. Бєлова (голов. ред.) [та ін.]. - Харків : Вид-во ХарРІ НАДУ "Магістр", 2018. - Вип. 1 (53). - С.143 - 152.

11. Тильчик О. В. Особливості державного управління Федеративної Республіки Німеччина та Польщі: досвід для України / О. В. Тильчик, Ю. Ю. Нерода // Порівняльноаналітичне право. - 2015. - № 1. - С. 223-226.

12. Хачатурян Х. В. Переорієнтація державного управління на потреби громадян: нова європейська модель та України / Х. В. Хачатурян // Вісник Київського міжнародного університету. - К. : КиМУ. - 2009. - Вип. 8. - 352 с. - Режим доступу: http://www.kymu.edu.ua/vmv/v/08/khachaturian.htm.

13. Соломатина Е. Д. Государственное управление в условиях глобализации и информатизации экономики: зарубежный опыт / Е. Д. Соломатина, Н. В. Шабуцкая // Социально-экономические явления и процессы. - 2015. - № 10. - С. 137-143.

\section{References:}

1. Vlasenko, S. G. (2016). OptimIzatsiyni napryamki demokratizatsiyi derzhavnogo upravlinnya Ukrayini [Optimization directions of democratization of public administration of Ukraine]. Efektivnist derzhavnogo upravlinnya - Efficiency of public administration, 3, 290-296 [in Ukrainian]. 
2. Harrison, Sh. (2003). Svyazi s obschestvennostyu: vvodnyiy kurs [Public Relations: Introductory Course]. (G. Alpatova, Trans). Izdatelskiy Dom "Neva”, Saint Petersburg [in Russian].

3. Chapman, R., \& Hunt, M. (1987). Open Government. A Study of the Prospects of Open Government within the Limitations of the British political System. Londres: Routledge.

4. Grunig J.E., \& Grunig L. A. (1992). Models of PR and communication. In J. E. Grunig, Excellence in public relations and communication management. Hillsdale, NJ: Lawrence Erlbaum Associates.

5. Varyagina, A. A. (2014). Kriteriyi otsinki ta pokazniki efektivnostI protsesu gromadskoyi uchasti [Evaluation criteria and indicators of the effectiveness of the public participation process]. Teoretichni i prikladni problemi psihologiyi - Theoretical and applied problems of psychology, 3(35), 99-108 [in Ukrainian].

6. Wilcox, D. (2001). The Guide to Effective Participation. Brighton, UK: Partnership Books.

7. Solovih, V. P. (2009). KontseptsIya "sotsialnoyi derzhavi" ta yiyi vpliv na derzhavne upravlInnya [The concept of "welfare state" and its influence on public administration]. Aktualni problemi derzhavnogo upravlInnya - Actual problems of public administration, 2, 71-80. Retrieved from http://nbuv.gov.ua/UJRN/apdy_2009_2_10 [in Ukrainian].

8. Channing E. (1897). Istoriya Soedinennyih Shtatov Severnoy Ameriki (1765-1865) [History of the United States of North America (1765-1865)]. (A. Kamenskiy, Trans). Saint Petersburg: Tipografiya kontragenstva zhd. Retrieved from https://ushistory.ru/images/files/channing_US_H.pdf [in Russian].

9. Belej, I. (2010). ZarubIzhnIy dosvid demokratichnogo vryaduvannya ta mozhlivostI yogo zastosuvannya $\mathrm{v}$ ukrayinskiy praktitsi [Foreign Experience of Democratic Governance and Possibilities of its Application in practice,Ukrainian]. Derzhavne upravlinnya ta mistseve samovryaduvannya - Public Administration and Local Self-Government, 2(5). Retrieved from http://www.dridu.dp.ua/vidavnictvo/2010/2010_02(5)/10bimzup.pdf [in Ukrainian].

10. Tereshchenko, D. A. (2018). Priynyattya upravlinskih rishen u diyalnostI organiv derzhavnoyi vladi: analIz svitovogo dosvidu [Management decision-making in the activity of public authorities: analysis of world experience]. L. O. Belov (Eds.), Aktualni problemi derzhavnogo upravlinnya - Actual problems of public administration. (Vols. 1 (53)), (pp. 143-152). Kharkiv: The issue of Harri Nadu "Master" [in Ukrainian].

11. Tilchyk. O.V., \& Neroda, Yu. Yu. (2015). OsoblivostIi derzhavnogo upravlinnya Federativnoyi Respubliki Nimechchina ta Polschi: dosvid dlya Ukrayini [Features of State Administration of the Federal Republic of Germany and Poland: Experience for Ukraine]. PorIvnyalno-analItichne pravo - Comparative-Analytical Law, 1, 223-226 [in Ukrainian].

12. Khachaturyan, Kh. V. (2009). PereorIentatsiya derzhavnogo upravlinnya na potrebi gromadyan: nova Evropeyska model dlya Ukrayini [The reorientation of public administration to the needs of citizens: a new European model for Ukraine]. VIsnik Kiyivskogo mizhnarodnogo universitetu - Bulletin of the Kiev International University, 8, 352. Retrieved from http://www.kymu.edu.ua/vmv/v/08/khachaturian.htm.

13. Solomatina, E.D., \& Shabutskaya, N.V. (2015). Gosudarstvennoe upravlenie v usloviyah globalizatsii i informatizatsii ekonomiki: zarubezhnyiy opyit [Public administration in the context of globalization and informatization of the economy: foreign experience]. Sotsialnoekonomicheskie yavleniya i protsessi - Socio-economic phenomena and processes, 10, 137-143 [in Russian]. 